

\title{
QUALITY ASSURANCE SYSTEMS OF HIGHER EDUCATION - THE CASE OF EUROPEAN INSTITUTIONS: ORIGIN, EVOLUTION AND TRENDS
}

\author{
Ángela Corengia, Doutora \\ Universidad Austral \\ acorengia@austral.edu.ar \\ Juan Carlos Del Bello, Especialista \\ Universidad Nacional de Río Negro \\ info@unrn.edu.ar \\ María Pita Carranza, Mestre \\ Universidad Austral \\ MPita@austral.edu.ar \\ Cecilia Adrogué, Doutora \\ UdeSA-Universidad Austral-CONICET \\ cadrogue@gmail.com
}

Recebido em 07/junho/2013

Aprovado em 25/julho/2014

Sistema de Avaliação: Double Blind Review



Esta obra está sob uma Licença Creative Commons Atribuição-Uso. 


\begin{abstract}
The purpose of this research is to analyze the origin, evolution, performance and trends of higher education quality assurance systems in the following European countries: Denmark, Norway, Sweden, Finland, Austria, Italy, Switzerland, Germany, Netherlands, United Kingdom and France. It also studies the performance and impact of the organizations that join the European Quality Assurance Agencies together. The main sources of data collection were in situ semi-structured interviews to members of these agencies. It was found that in higher education institutions there is a strong trend towards the development of 'internal quality assurance systems' in response to the public policies known as 'quality audits'.
\end{abstract}

Keywords: Quality Assurance Systems. Quality Audits. Higher Education in Europe.

\title{
RESUMEN
}

El propósito de esta investigación es analizar el origen, la evolución, el funcionamiento y las tendencias de los sistemas de aseguramiento de la calidad de la educación superior de los siguientes países europeos: Dinamarca, Noruega, Suecia, Finlandia, Austria, Italia, Suiza, Alemania, Holanda, Reino Unido y Francia. También se estudia el funcionamiento e impacto de las organizaciones que agrupan a las Agencias Europeas de Aseguramiento de la Calidad. Las fuentes principales de recolección de la información fueron las entrevistas semiestructuradas realizadas in situ a integrantes de estas agencias. Se halló que en las instituciones de Educación Superior existe una fuerte tendencia hacia el desarrollo de 'sistemas internos de aseguramiento de la calidad' en respuesta a políticas públicas denominadas 'auditorías de calidad'.

Palabras claves: Aseguramiento de la Calidad. Auditorías de Calidad. Educación Superior en Europa. 


\section{INTRODUÇÃO}

Quality assessment in higher education is one of the key issues in the agenda of higher education reform processes. The new agenda is the result of the interaction of different political, social and economic factors, which caused a revision of the relationship between the State and society, as well as the relationship between the State and the universities (Krotsch, 1999; 2001).

In the last years there has been a remarkable increase in the adoption of higher education quality assurance systems. "Quality assurance" involves a great number of mechanisms and procedures with the purpose of ensuring a desired quality in accordance with the specific mission of each institution or with previously established standards for programs and institutions. According to this, quality assurance implies the design and implementation of both evaluation and accreditation processes (Harvey and Green, 1993).

Despite more than two decades of quality assurance, there has not been much substantive research regarding the impact of quality assurance at higher education. Beyond the anecdotic, there is a lack of evidence.

This study seeks to show what is taking place in European countries in a descriptive and purposeful (trends) way. The intention is to present a comparative analysis of the origin, evolution, performance and trends of higher education quality assurance systems in the following European countries: Denmark, Norway, Sweden, Finland, Austria, Italy, Switzerland, Germany, Netherlands, United Kingdom and France. The performance of the organizations called "umbrellas" of the European Agencies of Quality Assurance -European Association for Quality Assurance in Higher Education (ENQA), the European Consortium for Accreditation (ECA) and the European Quality Assurance Register for Higher Education (EQAR)- is also analyzed.

Next section presents a theory approximation to Quality Assurance Systems, in section three the method used for the study is described, section four describes the origin, evolution and trends of the quality assurance systems, section five presents the performance of the European quality assurance agencies "umbrella organizations" and section six concludes..

\section{THEORY APPROXIMATION TO QUALITY ASSURANCE SYSTEMS}

Introduction of systematic evaluation procedures at the national systems level implies a redistribution of the relationships between the authority of the State, the academic and 


\section{QUALITY ASSURANCE SYSTEMS OF HIGHER EDUCATION - THE CASE OF EUROPEAN \\ INSTITUTIONS: ORIGIN, EVOLUTION AND TRENDS \\ DOI: http://dx.doi.org/10.5007/1983-4535.2014v7n3p61}

institutional elites and the market and its agents (Brunner, 1994). In the literature reviewed, it was present the idea of university quality evaluation policies as a mechanism of redistribution of the central power of the State in relation with the universities. Moreover, power within higher education institutions is also redistributed. The consequence of this is a more remote control through public or private intermediate institutions -according to the countries- and a closer link with market mechanisms.

It can be asserted that in certain countries like the United States, evaluation and accreditation of higher education is an established practice. In other contexts such as European and Latin-American countries these policies and processes have been used for about twenty years, while Asian countries have introduced them during the late nineties.

In Europe, the establishment of the European Higher Education Area (EHEA) can be mentioned for its direct influence in the evaluation and accreditation processes. The Bologna Declaration (1999) and the subsequent meeting at Prague (2001) set measures in order to start the European Higher Education Area in 2010. The implementation of higher education quality evaluation systems is one of the most important measures adopted. The EHEA, with its 47 participating countries, is characterized by the diversity of political systems, higher education systems, socio-cultural and educative traditions, languages and expectations. As a consequence, a single approach to higher education quality, criteria and quality assurance is completely inappropriate.

Taking this into account, the European Association for Quality Assurance in Higher Education developed the "Standards and Guidelines for Quality Assurance in the European Higher Education Area." This report consists of three parts. Part 1: European standards and guidelines for internal quality assurance within higher education institutions. Part 2: European standards and guidelines for the external quality assurance of higher education. Part 3: European standards and guidelines for external quality assurance agencies.

The evaluation and accreditation of university quality has become the center of debates and worries among the higher education field (Brunner, 1994). This trend has taken place in different countries.

Following Harvey (2008), the main question that arises is whether higher education quality is really improving or it just appears to. If higher education is improving, what has improved? Has something been done beyond making things look better? How do we know? Is 
quality assurance the main tool for improvement? How has quality assurance been achieved? Did the 20 years of quality assurance have any impact?

Harvey (2008) states that the 'impact' is a difficult concept in itself. In particular if one intends to measure it as a simple cause-effect relationship. Even though there is certain direct impact of the processes to assure quality, such as the production of documents and audit reports, this production does not necessary traduces into changes in the quality.

An alternative approach suggests that activities performed by quality assurance agencies, combined with internal processes within institutions, situated in a broader market or governmental context, promote changes in activities, perspectives and attitudes. Implementation of international, national and institutional policies takes place in unintended or unanticipated ways by those who generated the policy.

This author states that maybe, the exploration of the impacts lies too much in positivist approaches that search a naïve cause-effect relationship. Phenomenological or positivist approaches provide more of the same.

Stensaker (2007) and Harvey (2008) also prevent a simple direct impact of quality assurance and state that the impact of quality can be interpreted differently depending on the starting point. These authors identify four areas of impact: 1) power, 2) professionalism, 3) permeability and 4) public relations. Regarding the first one, they note that the quality assurance process support the development of an institutional leadership in higher education that is observed through the raising centralization of the information and much clear lines of responsibility, though removing some of the responsibilities of the individual academic. In the second one, quality work has become more professional, with "written routines, scripts, handbooks and rules that provide hints of when to do what, and who is in charge. Some just see this as increased bureaucracy while others regard it as making 'tacit knowledge' transparent" (Stensaker, 2007:60). The third argument states that quality assurance has led to a great increase of information and that we probably know much more about higher education than before. The fourth states that quality processes are used as a marketing tool and as a mechanism of defense against rankings and performance indicators systems that have risen around the world.

As a result, Harvey (2008) concludes that quality assurance has had an impact. Though it is still unclear whether the learning experience of the students has improved. $\mathrm{He}$ believes that the students participate of the learning process; they are not a product, a client or 
consumer. Education is not a service for a client and even less a product to be consumed, but a continuous transformation process of the participating student.

At the same time, the combination of three theoretical perspectives: "the organizational analysis" (Clark 1983), the "new institutionalism in the organizational analysis" (Powell and Dimaggio, 1991) and the "model to evaluate the impact of a public policy" (Brunner and Martinez Nogueira, 1999) can provide interesting tools to evaluate the effects in terms of improvements of the quality assurance systems.

In the first perspective, the approach concentrates the attention in the way the system determines the action and change. Clark (1983) has identified a number of tendencies, and highlights the need to specify the levels in which the change takes place.

In the second approach the authors emphasize the capacity of the institutions to influence the people. In the two extremes, the change can be considered reactive -when it comes from external sources- or substantive -when it comes from endogenous sources.

The model provided by Brunner and Martinez Nogueira (1999) in order to evaluate the impact of a public policy, proposes to identify the changes produced by its implementation. These changes can have as results, in turn, processes and products of higher quality, efficiency and equity, and lead -or not- to changes in the organizational culture.

\section{METHOD}

The main source of information was in situ visits to 15 quality assurance agencies, located in the 11 mentioned countries. This information was complemented and updated with secondary sources, particularly the review of specific literature and agencies' web sites. In Table 1, we present the country, city and name of the agencies, as well as the abbreviation, the date of the interview and the name and position of the people interviewed. 


\section{QUALITY ASSURANCE SYSTEMS OF HIGHER EDUCATION - THE CASE OF EUROPEAN \\ INSTITUTIONS: ORIGIN, EVOLUTION AND TRENDS \\ DOI: http://dx.doi.org/10.5007/1983-4535.2014v7n3p61}

Table 1 Country, city, name of the Agency, abbreviation, date of the interview and name and position of the people interviewed

\begin{tabular}{|c|c|c|c|c|c|c|}
\hline & Country & City & Name of the Agency & Abbreviation & $\begin{array}{l}\text { Date of the } \\
\text { Interview }\end{array}$ & $\begin{array}{c}\text { Name and Position of } \\
\text { the People } \\
\text { Interviewed }\end{array}$ \\
\hline 1 & Denmark & Copenhague & $\begin{array}{l}\text { The Danish Evaluation } \\
\text { Institute }\end{array}$ & EVA & $\begin{array}{l}\text { August } 27 \\
2008\end{array}$ & $\begin{array}{l}\text { - Tine Holm (Director } \\
\text { of Projects of Higher } \\
\text { Education) }\end{array}$ \\
\hline 2 & Norway & Oslo & $\begin{array}{l}\text { Nasjonalt Organ for } \\
\text { Kvalitet I Utdanningen } \\
\text { Utdanningen (Norwegian } \\
\text { Agency For Quality } \\
\text { Assurance In Education) }\end{array}$ & NOKUT & August 29 & $\begin{array}{l}\text { - Gro Hanne Aas } \\
\text { (Senior Adviser, } \\
\text { Section For Quality } \\
\text { Systems) } \\
\text { - Luna Lee Solheim } \\
\text { (Adviser, Section For } \\
\text { Accreditation) }\end{array}$ \\
\hline 3 & Sweden & Stockholm & $\begin{array}{l}\text { Högskoleverket - The } \\
\text { Swedish National Agency } \\
\text { For Higher Education }\end{array}$ & NAHE & September 2 & $\begin{array}{l}\text { - Jean-Pierre Zune. } \\
\text { (Project Manager) } \\
\text { - Jana Hejzlar. (Project } \\
\text { Manager) }\end{array}$ \\
\hline 4 & Finland & Helsinki & $\begin{array}{l}\text { Finnish Higher Education } \\
\text { Evaluation Council }\end{array}$ & FINHEEC & September 4 & $\begin{array}{l}\text { - Helka Kekäläinen } \\
\text { (Secretary-General) } \\
\text { - Matti Kajaste } \\
\text { (Adviser) }\end{array}$ \\
\hline 5 & Austria & Viena & $\begin{array}{l}\text { Österreichischer } \\
\text { Akkreditierungsrat } \\
\text { (Austrian Accreditation } \\
\text { Council) }\end{array}$ & OAR (AAC) & September 9 & - Elisabeth Fiorioli \\
\hline 6 & $\begin{array}{l}\text { Switzerla } \\
\text { nd }\end{array}$ & Berne & $\begin{array}{l}\text { Organ Für Akkreditierung } \\
\text { Und Qualitätssicherung } \\
\text { Der Schweizerischen } \\
\text { Hochschulen (Center of } \\
\text { Accreditation and Quality } \\
\text { Assurance of the Swiss } \\
\text { Universities) }\end{array}$ & OAQ & September 12 & $\begin{array}{l}\text { - Rolf Heusser } \\
\text { (Director) }\end{array}$ \\
\hline 7 & Germany & Bayreuth & $\begin{array}{l}\text { Akkreditierungs, } \\
\text { Certifizierungs Und } \\
\text { Qualitätssicherungs } \\
\text { Instituts (Accreditation, } \\
\text { Certification and Quality } \\
\text { Assurance Institute) }\end{array}$ & ACQUIN & September 15 & $\begin{array}{l}\text { - Helke Biehl } \\
\text { (Gremienbetreuung) } \\
\text { - Christoph Affeld } \\
\text { (Referent) }\end{array}$ \\
\hline 8 & Germany & Bonn & $\begin{array}{l}\text { Stiftung Zur } \\
\text { Akkreditierung Von } \\
\text { Studiengängen In } \\
\text { Deutschland (Foundation } \\
\text { for the Accreditation of } \\
\text { Study Programmes in } \\
\text { Germany) }\end{array}$ & $\begin{array}{l}\text { AKKREDITIE } \\
\text { RUNGSRAT }\end{array}$ & September 16 & $\begin{array}{l}\text { - Franz Börsch } \\
\text { (Programme Manager) }\end{array}$ \\
\hline 9 & Holland & Den Haag & $\begin{array}{l}\text { Nederlands-Vlaamse } \\
\text { Accreditatieorganisatie - } \\
\text { Accreditation Organisation } \\
\text { of the Netherlands and } \\
\text { Flanders }\end{array}$ & NVAO & September 18 & $\begin{array}{l}\text { - Mark Frederiks } \\
\text { (International Affairs) }\end{array}$ \\
\hline
\end{tabular}




\begin{tabular}{|c|c|c|c|c|c|c|}
\hline & Country & City & Name of the Agency & Abbreviation & $\begin{array}{l}\text { Date of the } \\
\text { Interview }\end{array}$ & $\begin{array}{c}\text { Name and Position of } \\
\text { the People } \\
\text { Interviewed }\end{array}$ \\
\hline 10 & Holland & Utrecht & $\begin{array}{l}\text { Netherlands Quality } \\
\text { Agency }\end{array}$ & NQA & September 19 & $\begin{array}{l}\text { - Nel Göbel (Auditor) } \\
\text { - Remco Van Der } \\
\text { Dussen (Auditor) }\end{array}$ \\
\hline 11 & $\begin{array}{l}\text { United } \\
\text { Kingdom }\end{array}$ & London & $\begin{array}{l}\text { British Accreditation } \\
\text { Council }\end{array}$ & BAC & September 22 & $\begin{array}{l}\text { - Stephen Vickers } \\
\text { (Chief Executive) } \\
\text { - Gina Hobson } \\
\text { (Accreditation } \\
\text { Manager) }\end{array}$ \\
\hline 12 & $\begin{array}{l}\text { United } \\
\text { Kingdom }\end{array}$ & Gloucester & $\begin{array}{l}\text { Quality Assurance Agency } \\
\text { For Higher Education }\end{array}$ & QAA & September 23 & $\begin{array}{l}\text { - Stephen Jackson } \\
\text { (Director of Reviews) }\end{array}$ \\
\hline 13 & France & Paris & $\begin{array}{l}\text { Agence D'evaluation De } \\
\text { Recherche Et De } \\
\text { L'enseignement Superieur }\end{array}$ & AERES & September 26 & $\begin{array}{l}\text { - Annick Rey (Delegate } \\
\text { for Quality and } \\
\text { Coordination Studies) }\end{array}$ \\
\hline 14 & Italy & Rome & $\begin{array}{l}\text { Comitato Nazionale Per La } \\
\text { Valutazione Del Sistema } \\
\text { Universitario (National } \\
\text { Comity for the evaluation } \\
\text { of the of the university } \\
\text { system) }\end{array}$ & CNVSU & September 11 & $\begin{array}{l}\text { - Guido Fiegna } \\
\text { (Membro di Comitato) } \\
\text { - Alessio Ancaiani } \\
\text { (Membro di Segreteria } \\
\text { Tecnica) }\end{array}$ \\
\hline 15 & Finland & Helsinki & $\begin{array}{l}\text { European Association For } \\
\text { Quality Assurance In } \\
\text { Higher Education }\end{array}$ & ENQA & September 5 & $\begin{array}{l}\text { - Emmi Helle } \\
\text { (Secretary General) } \\
\text { - Nathalie Costes } \\
\text { (Project Manager) } \\
\text { - Teemu Suominen } \\
\text { (Project Coordinator) }\end{array}$ \\
\hline
\end{tabular}

Source: Personal interviews held by Angela Corengia and María Pita Carranza.

\section{ORIGIN, EVOLUTION AND TRENDS OF THE QUALITY ASSURANCE SYSTEMS}

In this section we present the origin, evolution and trends of the quality assurance systems in each country selected for the study, Table 2 shows a synthesis of the characteristics of the higher education systems of analyzed countries. 


\section{QUALITY ASSURANCE SYSTEMS OF HIGHER EDUCATION - THE CASE OF EUROPEAN \\ INSTITUTIONS: ORIGIN, EVOLUTION AND TRENDS \\ DOI: http://dx.doi.org/10.5007/1983-4535.2014v7n3p61}

Table 2 Characteristics of the Higher Education Systems in the European Countries analyzed.

\begin{tabular}{|c|c|}
\hline Country & Characteristics \\
\hline 1. Denmark & $\begin{array}{l}\text { - Structure: a) Short cycle of Higher Education; b) Middle cycle; c) University cycle. } \\
\text { - Most of them are public. } \\
\text { - They adopt Bologna process. }\end{array}$ \\
\hline 2. Norway & $\begin{array}{l}\text { - Structure: a) Universities; b) Specialized Universities; c) University Colleges. } \\
\text { - Most of them are public. } \\
\text { - Small Private sector, mostly financed by the State. } \\
\text { - There is no competition among both sectors. } \\
\text { - They adopt the Bologna process. }\end{array}$ \\
\hline 3. Sweden & $\begin{array}{l}\text { - Structure: a) Universities; b) Colleges. } \\
\text { - Most of them are public. } \\
\text { - They adopt the Bologna process. }\end{array}$ \\
\hline 4. Finland & $\begin{array}{l}\text { - Structure: a) Universities; b) Polytechnics or Universities of Applied sciences. } \\
\text { - Next system strucural reform: merge institutions.. } \\
\text { - Most of them are public. } \\
\text { - They adopt the Bologna process. }\end{array}$ \\
\hline 5. Austria & $\begin{array}{l}\text { - Structure: a) State universties-public; b) Private universities (12, since 1999); c) Universities } \\
\text { of Applied sciences. } \\
\text { - They adopt the Bologna process. }\end{array}$ \\
\hline 6. Switzerland & $\begin{array}{l}\text { - Structure: a) State Universities- Public; b) Universities of Applied Sciences. } \\
\text { - Federal System. } \\
\text { - Most of them are public. } \\
\text { - They adopt the Bologna process }\end{array}$ \\
\hline 7. Germany & $\begin{array}{l}\text { - Structure: a) Universities; b) Universities of Applied Sciences. } \\
\text { - Federal System. There was a big change, the State no longer manages the Higher Education } \\
\text { System. Institutions have more autonomy to decide their profile. } \\
\text { - They adopt the Bologna process. }\end{array}$ \\
\hline 8. Holland & $\begin{array}{l}\text { - Structure: a) Universities based on research: Academic Universities; b) Professional } \\
\text { Universities, of applied sciences. Public (14); Private (8). } \\
\text { - Flanders has a similar structure. } \\
\text { - Diploma of "professional bachelor-master"; and "academic bachelor-master". } \\
\text { - They adopt the Bologna process. }\end{array}$ \\
\hline $\begin{array}{l}\text { 9. United } \\
\text { Kingdom }\end{array}$ & $\begin{array}{l}\text { - Structure: a) Universities (119 -94 in England, } 9 \text { in Wales, } 14 \text { in Scotland y } 2 \text { in Northern } \\
\text { Ireland -); b) "Other type of Higher Education Institutions" (50 -37 in England; } 4 \text { in Wales; } 7 \text { in } \\
\text { Scotland; } 2 \text { in Northern Ireland-). } \\
\text { - Autonomous. They do not belong to the government, nor are directed by it. } \\
\text { - Centralized public funding. } \\
\text { - They adopt the Bologna process. }\end{array}$ \\
\hline 10. France & $\begin{array}{l}\text { - Structure: a) Universities; b) Schools (Écoles, Elite institutions); c) Research organizations. } \\
\text { - Public System. Only } 10 \% \text { of the students assist to private institutions. } \\
\text { - They adopt Bologna process. }\end{array}$ \\
\hline 11. Italy & $\begin{array}{l}\text { - Structure: a) State Universities; b) Non-State Universities; c) Thematic Universities, distance } \\
\text { learning. All are considered public. } \\
\text { - They adopt the Bologna process }\end{array}$ \\
\hline
\end{tabular}

Source: Own estimation based on information obtained in the interviews and updated based on information obtained on websites.

In Denmark, The Danish Evaluation Institute (EVA), a unique public agency independent of the Ministry of Education, operated from 1992 to 2007. In the beginning, this agency was in charge of accrediting university programs, but since 1999, it accredited all higher education programs, not just university ones. In 2004, the "institutional audit" was implemented, in order to establish internal quality assurance systems within institutions. 
Therefore, the system shifted from "program evaluation" to "institutional audit." In the year 2007 the Accreditation Agency (ACE) was created. This agency is focalized in the accreditation of university programs, while the Danish Evaluation Institute (EVA) is in charge of accrediting non-university higher education programs. Actually, the trend in this country is to go back to "institutional audits" with a random system of "program accreditation". The aim of this change is to achieve a higher impact at an institutional and strategic level.

In Norway, the Norwegian Agency for Quality Assurance in Education (NOKUT) exists since 2002. This agency is in charge of the accreditation of university programs and the evaluation of the internal quality assurance systems of higher education institutions. In this country, the trend is to reduce control of "ex-ante" details in programs" accreditation and to strengthen the evaluation of the "institutions' internal quality assurance systems". This measure seeks to enhance the confidence on institutions to be responsible for their quality. In these audits, whether the institutions have quality and the impact of institutional quality systems is verified.

In Sweden, the Swedish National Agency for Higher Education (NAHE) emerged in 1995. This agency assesses the rights of institutions to grant official certificates, subjects, and the change of status from Colleges to Universities. Notwithstanding, its main function is to perform rigorous "institutional audits". These audits verify whether institutions have internal quality assurance systems and the effects of these systems on institutional quality. Since 2007, it grants "excellence awards" to particular programs belonging to higher education institutions. In this country, the trend is to continue with the "institutional audits".

In Finland the Finnish Higher Education Evaluation Council (FINHEEC) was created in 1996. Though it evaluates higher education institutions as a whole, the evaluation focus lies in the "internal quality assurance systems". That is to say, it assesses how institutions control their own quality and how they improve their results. The main trend is to continue with the "institutional audit" with a voluntary system of "program accreditation", this latter in accordance with the international certificates validation.

In Austria a fragmented system is observed. Since 2000 there were three types of agencies: (1) the Austrian Accreditation Council (AAC) which mission is to accredit and reaccredit private universities; (2) an agency that accredits applied science universities; and (3) the Austrian Agency for Quality Assurance (AQA), for public universities. This agency is devoted to assist public institutions in the development of their "internal quality assurance 
systems." The system is voluntary. The trend observed at the moment of the interviews finally took place and the three agencies were unified into only one quality assurance agency for all institutions.

In Switzerland the Center for accreditation and Quality Assurance (OAQ) exists since 2001. This agency has the following tasks: (1) carry out "institutional audits" every 4 years, mandatory for universities and (2) perform the "voluntary programs accreditation" - except for Medicine which is mandatory-. In the "institutional audits", the agency is centered in the evaluation of the "internal quality assurance systems." The trend is that the agency will be more focused in institutional audit than programs' accreditation. It is considered that if a good "internal quality assurance system" exists, this guarantees that institutions are qualified to evaluate their own programs. That is to say, the institutions must be involved in programs' quality. The purpose of the agency must be to control how they do it and that they do it periodically and systematically.

In Germany, the Accreditation Council (AC) and 6 intermediate agencies exist since 1999. The Accreditation Council's mission is to supervise all German accreditation agencies and to promote a fair competence between them. The so called "intermediate agencies" are disciplinary agencies engaged to accredit undergraduate and postgraduate programs of all higher education institutions in Germany. The most important in programs' accreditation are not processes but results. In other words, both the objectives the institution has established for a certain program and the competences obtained by students are evaluated. It is considered that the process to obtain the results is part of the higher education institution autonomy. The trend in Germany is the "institutional audit". The Accreditation Council is still working, though as an "agency that accredits agencies." The agencies must obtain the license from the Accreditation Council to carry out the "institutional audits." In this way it is intended to reduce the bureaucracy in the programs' accreditation. Institutions are encouraged to develop their own "quality assurance systems" for internal accreditation in order to improve and certify the quality of their own programs. Therefore, what will be evaluated and accredited is the "internal quality assurance system." If the system is accredited, automatically all the programs will be accredited.

In Netherlands the Educational accreditation organization of Netherlands and Flanders (NVAO) exists since 2003. Its main function is to accredit programs. There are also 7 agencies in charge of the programs' external evaluation (NQA, QANU, FIBAA, ASIIN, and 
others). The universities can choose which agency will perform their external evaluation. Since 2010 there are "institutional audits", but the programs' accreditation continued. Though, if the institution overcomes the institutional audit, the programs' accreditation is easier. The "institutional audit" is mainly focused in "internal quality assurance systems."

Before 1997, in the United Kingdom (England, Wales and Scotland) there were two procedures for quality (1) institutional audit, which was responsibility of the Higher Education Quality Council and; (2) teaching quality evaluation, performed by the Funding Councils, in order to ensure the compliance with the standards for the funded programs. In 1997 the Quality Assurance Agency for Higher Education (QAA) was created with the mission of performing the "quality assurance integrated system." The universities asked for a merge of processes in order to avoid the duplication of efforts generated by the two separate quality assurance procedures. QAA evaluates the institution through the "quality institutional audits" every 6 years. The programs are responsibility of institutions, which are empowered to grant degrees. The trend in the United Kingdom is to continue with the "institutional audits" since it can be observed that universities are managing the quality efficiently.

In France, the National Committee for Evaluation (CNE), created in 1984 by the Higher Education Act, evaluated institutions recommending measures for improvement. It did not evaluate or accredit programs. In 2006 the Evaluation Agency for Research and Higher Education (AERES) was created by the new Research Act, and it is in functions since 2007. The main duties of the AERES are (1) institutional evaluation (similar to what the CNE did); (2) research unit evaluation; (3) programs' accreditation and categorization; (4) doctoral schools' accreditation and categorization. As in many other European countries, the trend is to evaluate "internal quality assurance processes" of higher education institutions.

In Italy the Comitato Nazionale per la Valutazione del Sistema Universitario (CNVSU) exists since 1999. This Committee is responsible of "accrediting institutions" based on minimum standards, as well of elaborating the national data base and information system. Unlike the other analyzed countries, the accreditation is not direct but through the "program accreditation". The trend is to create an agency in replacement of the Committee.

\section{EVALUATION OF THE EUROPEAN QUALITY ASSURANCE AGENCIES}

In this section we describe the performance of the "umbrella organizations" of European Quality Assurance Agencies: (1) European Association for Quality Assurance in 
Higher Education (ENQA), (2) European Consortium for Accreditation in Higher Education (ECA) and (3) European Quality Assurance Register for Higher Education (EQAR).

\section{European Association for Quality Assurance in Higher Education (ENQA)}

This association was created in 2000. Since 2004 it is an independent association from the Ministry of Education. It operates as a "quality seal" of the European quality assurance agencies. To become a "full member" of the ENQA the agencies must comply with the European Standards and Guidelines for Quality Assurance (ESG). The agencies that are "candidate members" have two years to demonstrate that they can achieve the required level to get the ENQA seal and become a full member.

\section{European Consortium for Accreditation in Higher Education (ECA)}

The consortium was created in the year 2003 as a cooperation area among agencies, in particular in what refers to the evaluation of procedures. The agencies members of the ECA consider that the mutual recognition of the accreditation decisions will contribute to the recognition of the qualifications and to the students' mobility in Europe.

\section{European Quality Assurance Register for Higher Education (EQAR)}

The European Quality Assurance Register for Higher Education (EQAR) - the Register- was created in 2007. Unlike the ENQA and the ECA, it is composed by the organizations of the so called "E4" group: (1) ENQA: European representatives of the quality assurance agencies; (2) ESU: European students association; (3) EUA: European universities association; (4) EURASHE: European Association of Institutions in Higher Education. The EQAR's task is to publish and administer a register of quality assurance agencies that comply substantially with the European Standards and Guidelines for Quality Assurance (ESG). It aims to provide clear and reliable information to the public regarding the quality assurance agencies that operate in Europe. The Register has a free access web site.

\section{CONCLUSION AND DISCUSSION}

From the analysis of the information obtained we can conclude that there is a strong trend of European quality assurance systems towards the strengthening of the "internal quality systems," that is to say, those that take place within higher education institutions. The "quality 
audit" or "institutional audit" is the policy instrument most widely used. It is inferred that reflection towards quality improvement generated within institutions is the most important issue achieved, although many times it is driven from external sources through public policy. These procedures promote autonomy and a greater responsibility for the own quality management in the higher education institutions.

It is considered that the effort to distinguish the means (evaluation process, accreditation) from the ends (higher education quality assurance) could be a step for both internal and external quality assurance systems. Moreover, worries about the bureaucratization that these processes can cause, and in fact they do, is not a minor issue. If this happens, these processes not only do not assure quality, but probably diminishes it. Indeed, it could be annulated. Through policy instruments, a quality culture within institutions can be motivated and facilitated from the outside -State, agencies, market and society-. This has been observed in the countries analyzed. In some of them it is already taking place, in others, it is the observed tendency.

The challenge of the ENQA, ECA and the Register is to help quality assurance agencies to have in mind that no one can give what one does not have, or that one can only give what one is, and has. If quality assurance agencies look to themselves, think about and evaluate their practices, they will be able to understand and help better the institutions they evaluate. However, it seems necessary to stop the growth of "umbrella" associations. Without noticing it, we may be moving away from the most important mission of a higher education institution: the knowledge, its generation and transmission. What should be a "virtuous circle" could become a vicious one.

It is still necessary to have more conclusive evidence as of where these processes produce improvement, and where they hinder and stop the essential in a higher education institution. A methodological difficulty cannot be the response to such a great shortage. Taking into account the time, money and people devoted to these processes, we cannot move forward without a scientific knowledge of their strengths and weakness.

Finally, we can assert that this overview about what is taking place in Europe may provide innovative instruments that could be considered for higher education quality evaluation and accreditation in Latin-American countries: quality audits, disciplinary agencies, evaluation of the quality assurance agencies, among others. 


\section{REFERENCES}

- Brunner, Joaquín. (1994), ‘Educación Superior en América Latina: coordinación, financiamiento y evaluación', in Marquís C. (Ed.), Evaluación Universitaria en el Mercosur. Buenos Aires: Ministerio de Cultura y Educación. Secretaría de Políticas Universitarias.

- $\quad$ Brunner, J. and R. Martínez Nogueira (1999), Evaluación preliminar y metodología para la evaluación de impacto. Infomec. Boletín Informativo del Fondo para el Mejoramiento de la Calidad Universitaria (FOMEC) 4(8), pp. 15-51.

- $\quad$ Clark, Burton (1983), The Higher Education System. Academic Organization in CrossNational Perspective. Berkeley: University of California Press.

- $\quad$ Harvey, Lee (2008), Assaying improvement. Conference. 30th Annual EAIR Forum "Polishing the silver: Are we really improving higher education?" Denmark Copenhagen, 2427 August 2008.

- $\quad$ Harvey, Lee and Green, Diana, (1993), 'Defining Quality', In Assessment and Evaluation in Higher Education, vol. 18, № 1, pp. 100-114.

- $\quad$ Krotsch, P. (1999), 'El proceso de formulación e implementación de las políticas de evaluación de la calidad en la argentina', in Un marco de calidad: evaluando la evaluación. Fifth conference of the Red Internacional de Agencias para el Aseguramiento de la Calidad en la Educación Superior. Santiago de Chile. Papers presented.

- $\quad$ Krotsch, P., (2001), Educación superior y reformas comparadas. Buenos Aires: Universidad Nacional de Quilmes.

- $\quad$ Powell, W. W. and DiMaggio, P. J. (1991), The New Institutionalism in Organizational Analysis. Chicago: The University of Chicago Press.

- $\quad$ Stensaker, B. (2007), 'Impact of quality processes', Embedding Quality Culture in Higher Education: selection of papers from the 1st European Forum for Quality Assurance 2007 (available online at:

www.eua.be/fileadmin/user_upload/files/Publications/EUA_QA_Forum_publication.pdf).

\section{Agencies' Web site}

- $\quad$ EVA: http://www.eva.dk

- $\quad$ NOKUT: http://www.nokut.no Sweden: http://english.hsv.se

- OAR (Austria): http://www.akkreditierungsrat.at 
- CNVSU: http://www.vsu.it OAQ (Switzerland): http://www.oaq.ch

- ACQUIN: http://www.acquin.org

- Akkreditierungsrat (Germany): http://www.akkreditierungsrat.de

- NVAO: http://www.nvao.net NQA: http://www.nqa.nl

- BAC: http://www.the-bac.org

- QAA: http://www.qaa.ac.uk

- AERES: http://www.aeres-evaluation.fr

- ENQA: www.enqa.eu

- $\quad$ EQAR: $\underline{w w w . e q a r . e u}$

- ECA www.ecaconsortium.net 